\title{
Characterization and optimization for beverage manufacture using Korean red ginseng extract
}

\author{
Ji-Won Choi, Mi-Jin Oh, Sang Keun Ha, Yongkon Park, Ho-Young Park* \\ Korea Food Research Institute, Seongnam 13539, Korea
}

기호성 개선 인삼농축액 제조를 위한 추출 조건 설정

\author{
최지원 · 오미진 · 하상근 · 박용곤 · 박호영* \\ 한국식품연구원
}

\begin{abstract}
This study was designed to develop a manufacturing process for ginseng concentrate with reduced unpleasant aroma and bitter taste. Two types of ginseng, white and red, were extracted under six different conditions (the 1st to the 6th step) of temperature $\left(65 \sim 95^{\circ} \mathrm{C}\right)$ and ethanol concentration $(0 \sim 70 \%)$. Six extracts of each ginseng were evaluated by a sensory test, and assayed for crude saponin, ginsenosides, and acidic polysaccharides. The content of crude saponin in the extracts decreased with extraction time. There was no significant difference in the crude saponin content between white and red ginseng extracts. The yield of red ginseng extract was higher (45\%) than that of white ginseng. No significant difference was observed in the acidic polysaccharide content between red and white ginseng extracts. $\mathrm{Rg}_{3}$, a specific ginsenoside in red ginseng, was detected in the 1 st to 6 th extracts of red ginseng. Bitterness, astringency, and sourness of ginseng extracts decreased as the extraction steps proceeded. The composite of the 1st, 2nd, and 6th step extracts decreased bittemess and astringency, and the highest overall acceptance. Compared with commercial beverages, the composition of the three extracts is the desirable method to decrease the bitter and astringent tastes, and the overall unpleasant flavor of ginseng.
\end{abstract}

Key words : Panax ginseng, red ginseng, sensory, bitterness, beverage

\section{서 론}

국민소득의 향상과 노인인구가 급증하면서 건강보조식 품인 인삼제품의 소비가 증가추세이다. 최근의 인삼의 건 강보조식품은 여러 형태로 유통되고 있으나 그 중에서 소비 자가 간편하게 복용할 수 있는 인삼추출액의 소비가 증대되 고 있다(1).

인삼(Panax ginseng C. A. Meyer)은 오가피 나무과 인삼 속에 속하는 다년생 초본류로서 수 천년동안 동양에서 민간 요법에 의한 경험적 효능에 의해 영약으로 알려져 있으며, 인삼의 과학적 연구는 약리학자인 Brekmann에 의해 사포

*Corresponding author. E-mail : hypark@kfri.re.kr Phone : 82-31-780-9347, Fax : 82-31-709-9876

Received 23 December 2015; Revised 4 April 2016; Accepted 4 April 2016.

Copyright (c) The Korean Society of Food Preservation. All rights reserved.
닌 유효설이 제창되며 본격적인 연구가 시작되었다. 근래 에는 약 38 종 진세노사이드의 분석기술이 발전하고 면역력 개선(2), 간 기능 개선(3), 항암 효과(4), 항산화(5), 항 당뇨 (6), 심혈관 장애 개선(7) 작용 등의 약리작용이 밝혀지면서 인삼은 의약품으로서는 물론 인삼차와 인삼 드링크류와 같은 기호성이 강조된 건강식품으로 발전되어 인삼의 가공 제품이 다양화되고 있다. 반면 이런 약리 효능에도 불구하 고 근채류 특유의 향과 쓴맛이 강하여 섭취가 용이하지 못하기 때문에 상품화가 까다롭기 때문에 가공제품 영역확 장을 위해서는 기호성이 개선된 농축액 베이스 개발이 우선 시 되어야 한다.

국내외에서 판매 및 이용되는 인삼제품은 크게 원형삼과 2 차 가공품으로 구분할 수 있다. 원형삼은 크게 수삼, 백삼, 홍삼으로 구분되는데 수삼은 밭에서 캐낸 후 마르지 않도록 보관한 인삼으로 70 80\% 수분을 함유하고 있으며, 백삼은 원료수삼의 표피를 벗기거나 열풍 혹은 일광 건조하여 가공 한 것으로 수분함량이 $14 \%$ 이하가 되도록 제조한 것으로 
높은 저장성으로 한방의학에서 가장 많이 사용하고 있는 인삼이다. 홍삼은 수삼을 물 또는 증기로 쪄서 건조한 것으 로 증숙과 건조 공정 중 비효소적 갈색화 반응(maillard reaction)이 일어나 갈색을 띄는 것이 특징이다(8). 가공원료 라는 관점에서 보면 홍삼은 백삼에 비하여 열처리 과정이 적용된 점 이외에 근본적인 차이가 있는 것은 아니다(9). 백삼, 홍삼 그대로의 상태로 건강식품으로 사용되어 오던 인삼류는 가공방법에 따라 그 생리활성 효능이 달라지면서 열 및 효소 등의 처리에 의해 인삼제품이 가공되어 맞춤형 제품 등이 출시되고 있다(10).

최근 인삼 음료 개발은 인삼 특유의 쓴맛을 낮추기 위해 꿀, 과당, 설탕 등의 당이 첨가되거나 당귀, 대추, 감초 등 단맛을 내는 한약재의 추출물이 혼합되어지고 있다. 그러 나, 건강에 대한 관심이 증가함에 따라 식품 구성 성분도 주요 관심사이고 비만 등 성인병과 관련하여 저칼로리의 음료를 선호하고 있어 다량의 당을 첨가한 제품의 경우 소비자의 선호도가 낮으며, 당귀, 대추, 감초 등의 한약재 추출물은 한약재의 특유한 향과 맛이 기호도를 감소시켜 그 섭취가 용이하지 못하다.

본 연구는 고려인삼의 소비 촉진 및 수출상품 다양화를 위해 백삼과 홍삼을 이용하여 추출단계별로 농축액을 제조 하고 이들의 진세노사이드 구성, 산성다당체와 같은 특성 을 확인하고 기호성 평가를 통해 인삼특유의 향과 쓴맛을 저감화 하는 추출 조건을 확립하여 얻어진 농축액으로 맛과 향을 개선한 인삼가공제품군을 다양화 하고자 한다.

\section{재료 및 방법}

\section{재 료}

본 실험에 시료로 사용한 홍삼은 금산군에서 2013년 수 확한 4년근 수삼을 홍삼제조방법(11)에 준하여 제조 후 사 용하였다. 추출에 사용한 주정은 대한주정라이프(Seoul, Korea)로부터 $95 \%$ 순도의 제품을 구입하여 사용하였다. 분석을 위한 표준물질은 Sigma Chemical Co.(St. Louis, MO, USA)로부터 구입하여 사용하였고 그 외 시약과 용매는 분석용 특급시약(Samchun Co., Pyeongtaek, Korea)을 사용 하였다.

\section{추출 단계별 농축액 제조}

백삼과 홍삼의 농축액 제조는 수분함량을 반영하여 건물 량 기준 $300 \mathrm{~g}$ 의 시료에 중량대비 15 배에 해당하는 4,500 $\mathrm{mL}$ 의 추출용매를 첨가하여 환류냉각기를 부착한 다음 일 정 온도로 조절되는 항온기에서 12 시간씩 1 차는 $70 \%$ 주정 에 $65^{\circ} \mathrm{C}, 2$ 차는 $60 \%$ 주정에 $75^{\circ} \mathrm{C}, 3$ 차는 $50 \%$ 주정에 $80^{\circ} \mathrm{C}$, 4 차 추출물은 $40 \%$ 주정에 $85^{\circ} \mathrm{C}, 5$ 차 추출물은 $20 \%$ 주정에 $90^{\circ} \mathrm{C}$ 그리고 6 차 추출물의 경우 물 $100 \%$ 에 $95^{\circ} \mathrm{C}$ 의 조건에
서 실시하였다. 각각의 추출액은 $45 \sim 50^{\circ} \mathrm{C}$ 에서 회전식 진공 증발기를 이용하여 적정 농도(약 $\left.40{ }^{\circ} \mathrm{Brix}\right)$ 로 농축하여 이용 하였다.

\section{추출 수율 측정}

추출조건을 달리한 백삼, 홍삼 추출액의 가용성 고형분 수율은 여과시킨 1 6차 추출액을 2,500 mL로 정용 후 이 중 $5 \mathrm{~mL}$ 씩을 취하여 미리 항량을 구한 수기에 넣고 $105^{\circ} \mathrm{C}$ 건조법(12)을 이용하여 고형분 함량을 계산하였다.

\section{조사포닌 함량 측정}

조사포닌 함량은 Shibata법(13)에 따라 다음과 같은 방법 으로 측정하였다. 각 농축액 $1 \mathrm{~g}$ 을 증류수 $60 \mathrm{~mL}$ 에 녹여 분액깔때기에 붓고 동량의 에틸에테르를 더한 다음 10 15 분간 충분히 교반 시킨 후 물 층과 에틸에테르 층이 완전히 분리될 때까지 방치시켰다. 분리된 에틸에테르 층은 제거 하고 남아 있는 물 층에 다시 수포화 부탄올 $60 \mathrm{~mL}$ 을 더하 여 다시 15 분간 충분한 교반 후에 물 층과 수포화 부탄올 층이 완전히 분리될 때까지 방치시켰다. 분리된 수포화 부 탄올 층을 따로 모아 놓고 물 층에 다시 수포화 부탄올을 붓는 과정을 3 회 반복하였다. 분리된 수포화 부탄올 층에 증류수 $50 \mathrm{~mL}$ 을 넣고 충분한 교반 후 다시 분리될 때까지 방치시킨 후 물 층만 제거하고 수포화 부탄올 층을 미리 항량을 구한 수기에 넣어 회전 진공 증발기를 사용하여 감압농축 후 드라이 오븐에서 2 시간 건조 항량을 구한 후, 무게를 측정하여 조사포닌 함량을 산출하였다. 시제품의 경우 $1 \mathrm{~g}$ 을 저울로 달아 증류수 $30 \mathrm{~mL}$ 에 녹여 위와 동일한 방법으로 조사포닌을 측정하였다.

\section{진세노사이드 함량 측정}

진세노사이드 함량은 조사포닌 측정과 동일하게 전처리 된 시료를 메탄올에 용해한 후 필터 $(0.45 \mu \mathrm{m})$ 로 여과하고 여과액을 HPLC(Waters e2695, Milford, MA, USA)를 사용 하여 기술표준원의 방법에 따라 분석하였다. 이때 컬럼은 YMC-Triart C18 column $(250 \times 4.6 \mathrm{~mm}, 12 \mathrm{~nm})$ 을, 검출기는 UV detector $(203 \mathrm{~nm})$ 를 사용하였다. 이동상으로는 $95 \%$ 이 상 순도의 $\mathrm{H}_{2} \mathrm{O}$ (용매 A)와 acetonitrile(용매 B)의 농도구배 조건을 사용하였는데 용매 $\mathrm{B}$ 를 기준으로 $20 \%$ (10분), $32 \%$ (40분), $50 \%$ (55분), $65 \%$ (70분), $90 \%$ (82분), $20 \%$ (90분) 이었다. 유속은 분당 $1.6 \mathrm{~mL}$ 이었으며 시료주입량은 $20 \mu \mathrm{L}$, 컬럼 온도는 $35^{\circ} \mathrm{C}$ 에서 실시하였다.

산성 다당체 함량 측정

백삼과 홍삼농축액의 산성 다당체 함량은 카바졸-황산 법(14)으로 측정하였다. 농축액 $1 \mathrm{~mL}$ (건조시료 $0.1 \mathrm{~g}$ )에 증류수를 가하여 50 배 희석하고 이중 $0.5 \mathrm{~mL}$ 을 취하여 카바 졸 $0.25 \mathrm{~mL}$ 와 진한황산 $3 \mathrm{~mL}$ 을 넣은 후 $85^{\circ} \mathrm{C}$ 에서 5 분 반응 시키고 실온에서 15 분 방치시킨 뒤 UV spectrometer 525 
$\mathrm{nm}$ 에서 흡광도를 측정하였다. 표준품으로는 D-galacturonic $\operatorname{acid}$ 를 증류수로 $2,4,6,8,10 \mu \mathrm{g} / \mathrm{mL}$ 농도가 되도록 조제하여 정 량곡선 $\left(\mathrm{y}=9.902 \mathrm{x}-0.006, \mathrm{R}^{2}=0.998\right)$ 을 작성하였으며 이를 이용하여 각 추출물의 산성다당체 함량을 환산하였다.

\section{선택적 홍삼농축액 모델 제조}

추출단계별로 얻은 홍삼농축액을 선택적으로 혼합하여 4종의 홍삼음료 모델을 제조하였다. 이때 인삼 농축액 제조 시 전체 수율을 고려하여 1 차, 2 차 추출 단계에서 얻은 농축 액은 모든 모델에 기본적으로 함유되게 하고, 3 차 추출단계 에서 얻은 농축액을 혼합한 RGB(red ginseng beverage)-1, 4차 농축액을 혼합한 RGB-2, 5차 농축액을 첨가한 RGB-3, 6차 농축액을 조합한 RGB-4로 각각 구분하였다. 농축액의 혼합 비율은 앞서 언급한 것과 같이 홍삼의 추출단계별 가용성 고형분 수율의 합을 100 으로 각 단계별 수율을 백분 율로 계산, 혼합하였다.

농축액 모델의 기호도 평가를 위한 음료는 식품공전상의 인삼·홍삼음료 제조/가공 기준(인삼사포닌 $80 \mathrm{mg} / \mathrm{g}$, 홍삼 사포닌 $70 \mathrm{mg} / \mathrm{g}$ 기준 $0.15 \%$ 이상)에 맞게 조사포닌 함량을 조정하고 정제수로 희석하여 제조하였다.

\section{묘사분석(descriptive analysis)에 의한 관능강도 및 기호도} 조사

검사원(judge)은 한국식품연구원에서 근무하는 25 30세 의 남성 3 명, 여성 12 명으로 총 15 명이 참여하였다. 본 실험 에서는 음료를 세 자리 난수표가 코드된 종이컵에 $4{ }^{\circ} \mathrm{C}$ 의 온도로 제공되었으며, 각 검사원에게 채점표를 나누어준 후 9점 척도에 의해 4가지 측정 항목(인삼향, 쓴맛, 떫은맛, 종합적기호도)의 강도를 측정하도록 하였다. 제시된 음료 는 무작위로 제공하여 순서상의 오차를 최소화하였다.

\section{통계 분석}

추출단계별 농축액과 모델의 관능적 특성 평가 및 기호 도 검사 결과에 대해 시료 간의 유의적 차이를 검증하기 위하여 분산분석(analysis of variance, ANOVA)을 수행하였 으며, 그 결과에 따라 Duncan의 다중 범위 검정법(Duncan's multiple range test)으로 유의성을 검증하였다 $(a=0.05)$. 통계 분석에는 SPSS for windows 12.0(SPSS Inc., Chicago, IL, USA)를 사용하였다.

\section{결과 및 고찰}

추출조건에 따른 백삼과 홍삼의 추출수율 변화

백삼과 홍삼을 추출용매와 추출온도를 각기 달리한 추출 단계별 추출액의 가용성 고형분 수율을 측정한 결과는 Table 1과 같다. 1 차 추출단계에서 백삼군과 홍삼군이 각각 $12.69 \%, 10.64 \%$ 로 백삼군의 수율이 높았으나, 전체 가용성 고형분 함량을 보면 백삼군과 홍삼군이 각각 $33.56 \%$, $48.79 \%$ 로 홍삼군이 백삼군에 비해 약 $15.23 \%$ 높은 추출 수율을 보였다. 홍삼군은 2 차 추출단계에서 추출수율이 $15.11 \%$ 로 가장 높았지만 3차 추출단계 부터 $10.34 \%$ 로 차수 가 증가할수록 추출수율은 감소하였고 백삼군 또한 차수가 증가 할수록 추출수율이 감소하였다.

1,2 차 추출단계까지의 가용성 고형분 합이 전체 함량 대비 $52.8 \%$ 로 나타났고, 1 차 추출단계에서 가용성 고형분 추출 수율이 $10.64 \%$ 로 백삼군 $12.69 \%$ 에 비해 낮았다. 이는 인삼 조직 내 전분질이 홍삼을 만드는 증삼, 가온건조과정 에서 호화되어 조밀이 치밀하고 견고하여 1차(70\% 주정, $65^{\circ} \mathrm{C}$ 추출온도) 추출단계에서 추출용매의 침투용이성이 낮 고 조직팽윤이 덜 일어남에 따라 추출 수율이 낮으며, 2차 추출단계부터는 조직팽윤이 일어나 추출 효율이 높아진 것으로 판단된다.

\section{추출단계별 인삼농축액의 조사포닌 함량 측정}

백삼과 홍삼 원물의 조사포닌 함량과 백삼과 홍삼의 추 출단계별로 제조한 인삼농축액의 조사포닌 함량을 측정한 결과는 Fig. 1과 같다. 전체 인삼의 조사포닌 함량은 백삼군 과 홍삼군이 각각 $56.44 \mathrm{mg} / \mathrm{g}, 53.15 \mathrm{mg} / \mathrm{g}$ 으로 백삼군이 약 $5.8 \%$ 높았다. 추출단계별 백삼과 홍삼추출물의 조사포 닌 함량은 추출용매의 주정 농도가 높을수록 추출액내 조사 포닌의 추출 이행량이 증가하는 경향을 나타내었다.

홍삼군의 경우 $70 \%$ 주정을 사용한 1 차 추출단계부터 물을 추출용매로 사용하는 6차 추출단계까지 추출 차수가 증가할수록 추출액내 조사포닌의 이행량은 $188.48,70.1$, $60.05,52.92,15.52,8.89 \mathrm{mg} / \mathrm{g}$ 으로 감소하였다. 홍삼군의 경우 1,2 차 추출단계에서 이행되는 조사포닌의 함량이 $188.48,70.1 \mathrm{mg} / \mathrm{g}$ 으로 다른 시료에 비해 높았다. 전체인삼 에 비해 1 4차 추출단계까지의 백삼군과 홍삼군의 조사포 닌 함량이 증가하였으나 5,6 차 추출단계에서는 감소하는

Table 1. Comparative extraction yield of both white and red ginseng according to six extraction steps

\begin{tabular}{|c|c|c|c|c|c|c|c|}
\hline \multirow{2}{*}{ Sample } & \multicolumn{7}{|c|}{ Extraction yield (\%) } \\
\hline & 1st extraction ${ }^{1)}$ & 2nd extraction ${ }^{2)}$ & 3rd extraction ${ }^{3)}$ & 4th extraction ${ }^{4)}$ & 5th extraction ${ }^{5}$ & 6th extraction ${ }^{6}$ & Total \\
\hline White ginseng & $12.69 \pm 0.34$ & $9.12 \pm 0.41$ & $4.57 \pm 0.10$ & $2.82 \pm 0.12$ & $2.12 \pm 0.08$ & $2.24 \pm 0.07$ & 33.56 \\
\hline Red ginseng & $10.64 \pm 0.40$ & $15.11 \pm 0.70$ & $10.34 \pm 0.02$ & $4.55 \pm 0.04$ & $4.21 \pm 0.10$ & $3.94 \pm 0.08$ & 48.79 \\
\hline
\end{tabular}

${ }^{1)} 65^{\circ} \mathrm{C} \quad 70 \% \mathrm{EtOH} ;{ }^{2)} 75^{\circ} \mathrm{C} 60 \% \mathrm{EtOH} ;{ }^{3)} 80{ }^{\circ} \mathrm{C} 50 \% \mathrm{EtOH} ;{ }^{4} 85^{\circ} \mathrm{C} 40 \% \mathrm{EtOH} ;{ }^{5} 90^{\circ} \mathrm{C} 20 \% \mathrm{EtOH} ;{ }^{6} 95^{\circ} \mathrm{C} 0 \% \mathrm{EtOH}$.

All extraction conditions performed for $12 \mathrm{hr}$. 


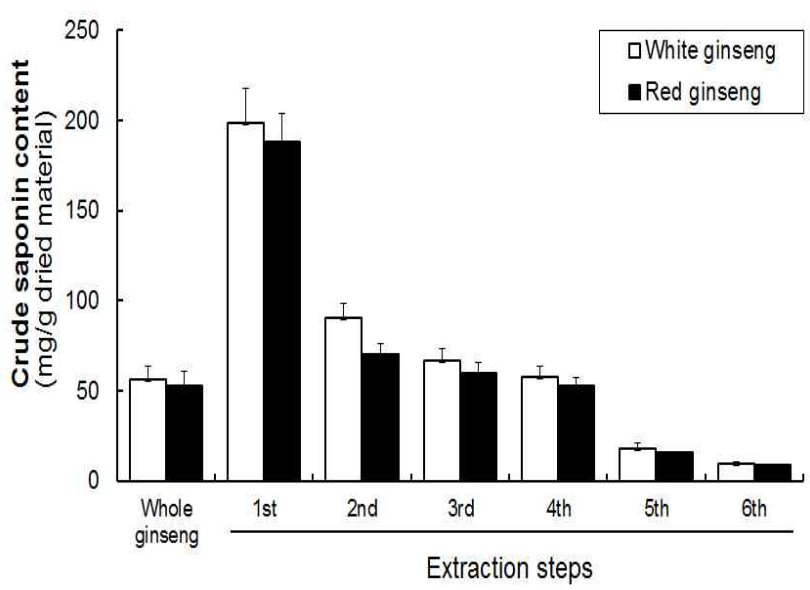

Fig. 1. Comparative concentrations of crude saponin between white and red ginseng extracts.

\section{경향을 보였다.}

추출조건에 따른 백삼과 홍삼의 산성다당체 함량 측정

추출단계별 백삼과 홍삼 농축액의 산성다당체 함량을 측정한 결과는 Table 2 와 같다. 추출단계가 진행됨에 따라 인삼농축액 내 산성다당체 함량은 증가하였으며, 1 4차 추 출단계까지는 홍삼군이 백삼군보다 $4.7 \sim 12.4 \%$ 높았으나, 5 차 추출단계는 백삼군이 $4 \%, 6$ 차 추출단계에서는 홍삼군 이 $1.2 \%$ 높게 나타났으며, 전체적으로 홍삼군이 백삼군에 비하여 산성다당체 함량이 $3.9 \%$ 높게 나타났다.

이는 단계별 인삼 추출액 제조시 추출시간은 12 시간으로 동일하나 단계별로 사용한 온도차이 즉, 1 차 추출단계 $65^{\circ} \mathrm{C}$ 보다 온도가 상승한 6 차 추출단계 $95^{\circ} \mathrm{C}$ 에서 조직 내 산성다 당체가 보다 많이 추출액으로 이행된 것으로 나타난 것으로 판단되며 인삼의 산성다당체는 추출온도가 높을수록 많이 추출되는 온도의존성이 큰 것으로 보고되어 있다(14).

인삼간 산성다당체를 비교하면 수삼이 백삼보다 많고 홍삼은 수삼보다 월등히 높은데 이는 인삼 다당체가 홍삼 제조과정 중의 한 과정인 증삼에 의해 가용화되기 쉬운 상태로 되어 더 많이 추출되기 때문이라 보고되어 있다(15).
크로마토그램은 Fig. 2에 나타내었고 이를 정량한 결과는 Table 3과 같다.

추출단계가 1 차에서 6 차로 진행됨에 따라 대부분의 major 진세노사이드 성분 $\left(\mathrm{Rg}_{1}, \mathrm{Re}, \mathrm{Rb}_{1}, \mathrm{Rc}\right)$ 들의 함량이 감 소하는 경향을 보였다. 백삼군의 경우 진세노사이드 총량 이 $\mathrm{Rb}_{1}>\mathrm{Re}>\mathrm{Rg}_{1}>\mathrm{Rc}$ 성분 순으로 함량이 높았고, 홍삼군의 경우 $\mathrm{Rg}_{1}>\mathrm{Rb}_{1}>\mathrm{Re}>\mathrm{Rc}$ 성분 순으로 함량이 높았다. 진세노 사이드 성분별 1 6차 추출단계까지의 총량과 각 추출단계 별 진세노사이드 성분의 총량은 백삼군과 홍삼군이 각각 $113.58 \mathrm{mg} / \mathrm{g}, 112.28 \mathrm{mg} / \mathrm{g}$ 로 홍삼군이 백삼군에 비하여 1.14 $\%$ 낮게 나타났다. 한편, 추출단계별 추출액의 진세노사이 드 성분 중 중추신경계에 작용하여 진정효과를 나타내는 $\mathrm{Rb} 1$ 을 살펴보면 1차 추출단계에서는 백삼시료와 홍삼시료 가 각각 $7.82,10.17 \mathrm{mg} / \mathrm{g}$ 으로 나타났다. 항 피로작용을 나타 내는 $\operatorname{Rg}_{1}$ 또한 1차 추출단계에서 백삼시료가 $9.3 \mathrm{mg} / \mathrm{g}$, 홍삼 군이 $11.38 \mathrm{mg} / \mathrm{g}$ 으로 높은 함유 분포를 보였고, 항 당뇨활성 을 나타내는 $\mathrm{Rb}_{2}$ 는 일정한 경향을 나타내지 않았다.

\section{추출단계별 홍삼추출액의 기호성 평가}

홍삼의 추출단계별 추출액을 $0.1 \%$ 음료로 제조하여 묘 사분석에 의한 기호도를 조사한 결과는 Table 4과 같다. 추출단계에 따른 음료 간 쓴맛, 떫은맛 관능강도는 유의적 인 차이가 확인되었는데 $(\mathrm{p}<0.05)$, 우선 쓴맛에서 1 차 추출 액이 6.64로 가장 강도가 높은 것으로 평가되었고 2 4차 추출액으로 진행될수록 평가점수는 낮아지나 시료 간 유의 차는 없었으며, 5, 6차 추출액은 평가점수가 각각 $2.27,2.09$ 로 다른 추출단계의 시료에 비해 현저히 낮은 결과가 확인 되었다. 떫은맛의 경우에는 4 차 추출액이 각각 6.33 으로 가장 강도가 높은 것으로 평가되었고, 그 다음으로 3 차, 5 차 추출액 순으로 강도가 높았는데 이는 추출단계 초기에 서 쓴맛 성분이 추출되어 4 차 추출 단계에서는 상대적으로 떫은맛이 상승되는 효과가 나타나는 것으로 판단된다. 맛 에서는 추출이 진행됨에 따라 강도가 낮아지지만 추출액 사이에 유의적 차이가 확인되지 않았다. 이들 결과는 $70 \%$, $60 \%$ 주정을 사용한 추출된 용매는 사포닌 함량이 높아 상대

Table 2. Comparative acidic polysaccharide contents of both white and red ginseng according to six extraction steps

\begin{tabular}{|c|c|c|c|c|c|c|c|}
\hline \multirow{2}{*}{ Sample } & \multicolumn{7}{|c|}{ Acidic polysaccharide content (mg/g) } \\
\hline & 1st extraction ${ }^{1)}$ & 2nd extraction ${ }^{2)}$ & 3rd extraction ${ }^{3)}$ & 4th extraction ${ }^{4)}$ & 5th extraction" & 6th extraction ${ }^{6)}$ & Total \\
\hline White ginseng & 129 & 137 & 149 & 186 & 223 & 248 & 1,072 \\
\hline Red ginseng & 135 & 154 & 164 & 196 & 214 & 251 & 1,114 \\
\hline
\end{tabular}

${ }^{1)} 65^{\circ} \mathrm{C} \quad 70 \% \mathrm{EtOH} ;{ }^{2} 75^{\circ} \mathrm{C} 60 \% \mathrm{EtOH} ;{ }^{3} 80{ }^{\circ} \mathrm{C} \quad 50 \% \mathrm{EtOH} ;{ }^{4} 85^{\circ} \mathrm{C} \quad 40 \% \mathrm{EtOH} ;{ }^{5} 90^{\circ} \mathrm{C} \quad 20 \% \mathrm{EtOH} ;{ }^{6} 95^{\circ} \mathrm{C} \quad 0 \% \mathrm{EtOH}$.

All extraction conditions performed for $12 \mathrm{hr}$.

추출단계별 백삼과 홍삼의 진세노사이드 함량 측정

본 연구에서 추출용매와 추출온도를 달리하여 추출단계 별로 제조한 인삼농축액의 진세노사이드 함량을 측정한
적으로 쓴맛이 강한 반면 $20 \%$, 물을 추출용매로 사용한 추출물은 쓴맛과 떫은맛이 약한 것을 확인하였다. 


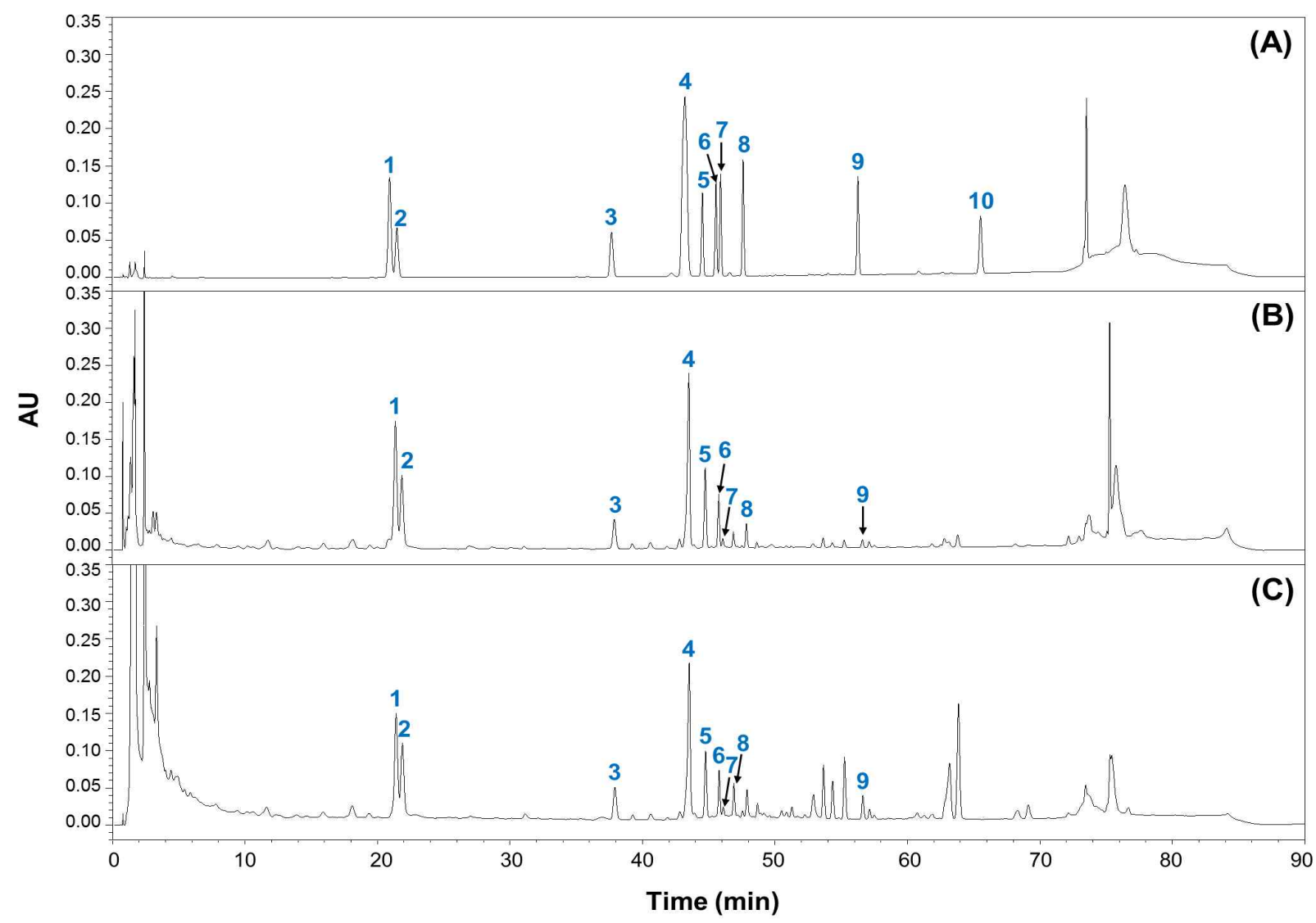

Fig. 2. HPLC chromatograms of (A) ginsenosides standard and extracts of (B) white ginseng and (C) red ginseng. 1, $\mathrm{Rg}_{1} ; 2$, Re; 3, Rf; 4, $\mathrm{Rg}_{2}+\mathrm{Rb}_{1} ; 5$, Rc; 6, Rb $;$;, $\mathrm{Rb}_{3} ; 8$, Rd; 9, $\mathrm{Rg}_{3} ; 10, \mathrm{Rh}_{2}$.

Table 3. Comparative ginsenosides contents of both white and red ginseng according to six extraction steps

\begin{tabular}{|c|c|c|c|c|c|c|c|c|c|c|c|c|}
\hline \multirow{2}{*}{\multicolumn{2}{|c|}{ Extraction steps ${ }^{1)}$}} & \multicolumn{11}{|c|}{ Ginsenosides (mg/g) } \\
\hline & & $\mathrm{Rg}_{1}$ & $\operatorname{Re}$ & $\mathrm{Rf}$ & $\mathrm{Rg}_{2}+\mathrm{Rh}_{1}$ & $\mathrm{Rb}_{1}$ & $\mathrm{Rc}$ & $\mathrm{Rb}_{2}$ & $\mathrm{Rb}_{3}$ & $\mathrm{Rd}$ & $\mathrm{Rg}_{3}$ & Total \\
\hline \multirow{7}{*}{$\begin{array}{l}\text { White } \\
\text { ginseng }\end{array}$} & $1 \mathrm{st}$ & 9.31 & 9.34 & 2.59 & 1.36 & 7.82 & 7.10 & 4.28 & 0.10 & 1.22 & $\mathrm{ND}^{2)}$ & 43.12 \\
\hline & 2nd & 6.91 & 5.31 & 1.79 & 0.83 & 6.71 & 4.55 & 2.95 & 0.58 & 1.28 & $\mathrm{ND}$ & 30.91 \\
\hline & $3 \mathrm{rd}$ & 4.65 & 3.58 & 1.15 & 0.63 & 4.91 & 3.00 & 1.98 & 0.40 & 1.08 & $\mathrm{ND}$ & 21.38 \\
\hline & 4 th & 1.33 & 2.75 & 0.30 & 0.38 & 3.48 & 0.91 & 0.61 & 0.11 & 0.25 & $\mathrm{ND}$ & 10.12 \\
\hline & 5 th & 0.10 & 2.06 & 0.23 & 0.10 & 1.19 & 0.68 & 0.45 & 0.09 & 0.19 & $\mathrm{ND}$ & 5.09 \\
\hline & 6 th & 0.39 & 1.42 & 0.08 & 0.06 & 0.51 & 0.27 & 0.18 & 0.05 & $\mathrm{ND}$ & $\mathrm{ND}$ & 2.96 \\
\hline & Total & 22.69 & 24.46 & 6.14 & 3.36 & 24.62 & 16.51 & 10.45 & 1.33 & 4.02 & - & 113.58 \\
\hline \multirow{7}{*}{ Red ginseng } & $1 \mathrm{st}$ & 11.38 & 8.08 & 2.36 & 1.28 & 10.17 & 7.97 & 4.47 & 1.04 & 1.56 & 0.55 & 48.86 \\
\hline & 2nd & 7.09 & 4.53 & 1.47 & 0.71 & 6.54 & 4.13 & 2.37 & 0.54 & 1.02 & 0.33 & 28.73 \\
\hline & $3 \mathrm{rd}$ & 4.42 & 2.85 & 0.86 & 0.34 & 4.21 & 2.07 & 1.24 & 0.29 & 0.64 & 0.20 & 17.12 \\
\hline & 4th & 3.10 & 2.11 & 0.60 & 0.25 & 3.51 & 1.62 & 1.01 & 0.27 & 0.54 & 0.17 & 13.18 \\
\hline & 5 th & 0.75 & 0.81 & 0.13 & 0.07 & 0.79 & 0.31 & 0.17 & 0.02 & 0.06 & 0.02 & 3.13 \\
\hline & 6th & 0.29 & 0.38 & 0.06 & 0.02 & 0.29 & 0.12 & 0.06 & 0.01 & 0.02 & 0.01 & 1.26 \\
\hline & Total & 27.03 & 18.76 & 5.48 & 2.67 & 25.51 & 16.22 & 9.32 & 2.17 & 3.84 & 1.28 & 112.28 \\
\hline
\end{tabular}

\footnotetext{
${ }^{1)} 1 \mathrm{st}, 65^{\circ} \mathrm{C} 70 \% \mathrm{EtOH} ; 2 \mathrm{nd}, 75^{\circ} \mathrm{C} 60 \% \mathrm{EtOH} ; 3 \mathrm{rd}, 80^{\circ} \mathrm{C} 50 \% \mathrm{EtOH} ; 4$ th, $85^{\circ} \mathrm{C} 40 \% \mathrm{EtOH} ; 5$ th, $90^{\circ} \mathrm{C} 20 \% \mathrm{EtOH} ; 6$ th, $95^{\circ} \mathrm{C} 0 \% \mathrm{EtOH}$

${ }^{2)}$ Not detected.
}

All extraction conditions performed for $12 \mathrm{hr}$. 
Table 4. Sensory scores ${ }^{1)}$ of red ginseng beverage $(\mathrm{RGB})^{2)}$ with six extraction steps

\begin{tabular}{ccccccc}
\hline Sensory attributes & ${\text { RGB- } 1 \mathrm{st} \mathrm{s}^{\mathrm{3}}}^{\mathrm{a}}$ & RGB-2nd & RGB-3rd & RGB-4th & RGB-5th & RGB-6th \\
\hline Bitterness & $6.64 \pm 2.06^{\mathrm{a})}$ & $5.18 \pm 1.60^{\mathrm{b}}$ & $5.00 \pm 1.53^{\mathrm{b}}$ & $4.09 \pm 1.14^{\mathrm{b}}$ & $2.27 \pm 0.79^{\mathrm{c}}$ & $2.09 \pm 0.83^{\mathrm{c}}$ \\
Astringency & $4.00 \pm 1.73^{\mathrm{ab}}$ & $3.33 \pm 0.58^{\mathrm{b}}$ & $5.33 \pm 1.15^{\mathrm{a}}$ & $6.33 \pm 1.15^{\mathrm{a}}$ & $5.00 \pm 2.65^{\mathrm{ab}}$ & $3.00 \pm 1.00^{\mathrm{b}}$ \\
Sourness & $3.64 \pm 1.63^{\mathrm{a}}$ & $3.36 \pm 1.75^{\mathrm{ab}}$ & $2.82 \pm 1.72^{\mathrm{ab}}$ & $2.73 \pm 1.19^{\mathrm{ab}}$ & $2.18 \pm 1.25^{\mathrm{b}}$ & $2.00 \pm 1.10^{\mathrm{b}}$ \\
\hline
\end{tabular}

${ }^{1)}$ Sensory scores were assessed on 9 point scale where $1=$ extremely bad, $9=$ extremely good. values represent means \pm SD $(n=20)$.

${ }^{2)}$ RGB (Red Ginseng Beverage) contains $70 \mathrm{mg} / \mathrm{g}$ of ginseng saponin.

${ }^{3)} \mathrm{RGB}-1 \mathrm{st}, 65^{\circ} \mathrm{C} 70 \% \mathrm{EtOH}$; RGB-2nd, $75^{\circ} \mathrm{C} 60 \% \mathrm{EtOH}$; RGB-3rd, $80^{\circ} \mathrm{C} 50 \% \mathrm{EtOH}$; RGB-4th, $85^{\circ} \mathrm{C} 40 \%$ EtOH; RGB-5th, $90^{\circ} \mathrm{C} 20 \%$ EtOH; RGB-6th, $95^{\circ} \mathrm{C} 0 \%$ EtOH.

${ }^{4)-c}$ Values with different superscript letters within the same row are significantly different at $\mathrm{p}<0.05$ by Duncan's multiple range test.

\section{선택적 홍삼농축액 모델의 기호성 평가}

홍삼음료는 사포닌 함량 $(70 \mathrm{mg} / \mathrm{g})$ 을 충족시키기 위하여 전체 사포닌 함유량의 $80 \%$ 가 넘는 1,2 차 추출물을 기본으 로 $3,4,5,6$ 차 추출물을 각각 추가한 후 쓴맛과 종합적 기호도를 확인한 결과는 Table 5 와 같다. 쓴맛의 경우 1 , 2 차 추출물에 3 차 추출물을 조합한 RGB-1에서 가장 높은 6.40으로 평가되었고, 반대로 6차 추출물을 조합한 RGB-4 에서는 RGB-1에 비해 유의적으로 낮은 5.00으로 평가되었 다.

홍삼에서 진세노사이드 추출 효율이 가장 좋은 주정 농 도는 $70 \%$ 이고 주정농도가 높아짐에 따라 진세노사이드 함량은 증가하지만 고형분 함량은 반대로 감소하는 경향을 나타낸다. 또한, 홍삼의 유효성분 추출 시 이용하는 $40 \%$ 이상의 에탄올 농도에서는 정유성분, 사포닌, 유기산 등은 잘 용해되나 단백질, 전분, 펙틴질 등의 고분자 물질은 거의 용출되지 않는다고 보고되고 있다(16).

상대적으로 조사포닌을 고함유하는 1 차, 2 차 추출액에 쓰지 않고 바디감을 부여할 수 있는 고분자 물질이 함유된 6차 농축액을 혼합한 RGB-4가 다른 모델에 비해 전반적 기호도도 상승하는 것으로 예측된다.
닌 $70 \mathrm{mg} / \mathrm{g}$ 기준 $0.15 \%$ 이상)에 맞도록 식용수에 희석하여 기호도를 비교하였다(Fig. 3). 쓴맛과 쓴맛 후미 강도는 선 택적 홍삼농축액 모델이 시판되고 있는 홍삼농축액에 비해 유의적으로 낮았고 인삼 향미 강도 또한 시료간 유의적 차이를 보여 선택적 홍삼농축액 모델 음료가 가장 약하였

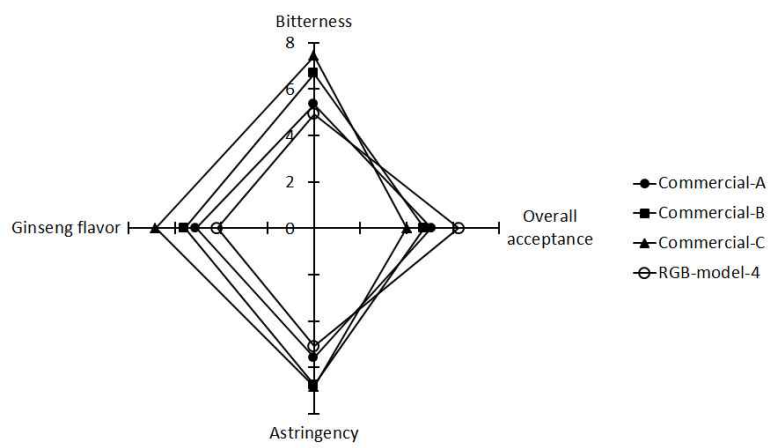

Fig. 3. Sensory evaluation and overall acceptability scores for developed red ginseng concentrate and three commercial red ginseng concentrate.

Represented data are mean scores of 20 panelists and different superscript letters are significantly different at $\mathrm{p}<0.05$ by Duncan's multiple range test.

Table 5. Composition of four red ginseng beverage (RGB)-models and their sensory score of bitterness and overall acceptance

\begin{tabular}{|c|c|c|c|c|c|c|c|c|c|}
\hline \multirow{2}{*}{ Samples } & \multicolumn{7}{|c|}{ Composition (\%) } & \multirow{2}{*}{$\begin{array}{l}\text { Bitterness } \\
\text { score }^{3}\end{array}$} & \multirow{2}{*}{$\begin{array}{c}\text { Overall } \\
\text { acceptance }\end{array}$} \\
\hline & $1 \mathrm{st}^{2)}$ & 2nd & $3 r d$ & 4th & 5th & 6th & Total & & \\
\hline $\mathrm{RGB}^{1)}$-model-1 & 43.3 & 38.9 & 17.8 & - & - & - & 100.0 & $6.40 \pm 1.84^{25)}$ & $5.07 \pm 1.4^{\mathrm{ab}}$ \\
\hline RGB-model-2 & 45.9 & 41.2 & - & 12.9 & - & - & 100.0 & $5.73 \pm 1.39^{\mathrm{ab}}$ & $5.73 \pm 1.79^{\mathrm{ab}}$ \\
\hline RGB-model-3 & 45.9 & 41.2 & - & - & 12.9 & - & 100.0 & $5.67 \pm 1.80^{\mathrm{ab}}$ & $6.13 \pm 1.55^{\mathrm{ab}}$ \\
\hline RGB-model-4 & 46.6 & 41.9 & - & - & - & 11.5 & 100.0 & $5.00 \pm 1.36^{b}$ & $6.83 \pm 1.84^{\mathrm{a}}$ \\
\hline
\end{tabular}

${ }^{1)}$ RGB, Red Ginseng Beverage.

${ }^{2)}$ st, $65^{\circ} \mathrm{C} 70 \% \mathrm{EtOH} ; 2$ nd, $75^{\circ} \mathrm{C} 60 \% \mathrm{EtOH} ; 3 \mathrm{rd}, 80^{\circ} \mathrm{C} 50 \% \mathrm{EtOH} ; 4$ th, $85^{\circ} \mathrm{C} 40 \% \mathrm{EtOH} ; 5$ th, $90^{\circ} \mathrm{C} 20 \% \mathrm{EtOH} ; 6$ th, $95^{\circ} \mathrm{C} 0 \% \mathrm{EtOH}$

${ }^{3}$ Sensory scores were assessed on 9 point scale where $1=$ extremely bitterness, $9=$ extremely bitterness.

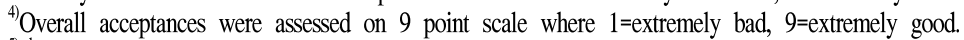

5a,b Values with different superscript letters within the same column are significantly different at $\mathrm{p}<0.05$ by Duncan's multiple range test $(\mathrm{n}=20)$.

선택적 홍삼농축액 모델의 기호성 비교 평가

선택적 홍삼농축액과 시판되고 있는 홍삼농축액 3종의 조사포닌 함량(A사, $54.94 \mathrm{mg} / \mathrm{g} ; \mathrm{B}$ 사, $45.29 \mathrm{mg} / \mathrm{g} ; \mathrm{C}$ 사, $31.60 \mathrm{mg} / \mathrm{g}$ )을 측정한 다음 홍삼음료 제조기준에(홍삼 사포
다. 음료의 기호도 평가결과에서도 유의적 차이를 보이며 본 연구에서 설정한 선택적 홍삼농축액 모델이 가장 좋은 것으로 나타났다. 따라서 홍삼을 추출용매를 달리하여 제 조한 추출단계별 농축액을 선택적으로 조합한 모델 음료 
는 쓴맛 등 음료 기호성 개선에 효과가 있음을 확인할 수 있었다.

\section{요 약}

백삼과 홍삼의 추출수율은 각각 $33.56 \%$ 와 $48.79 \%$ 로 홍 삼의 추출수율이 높았고, 산성다당체의 경우 1 4차 추출단 계까지는 홍삼군이 백삼군보다 높았으나, 5 차 추출단계에 서 백삼군이 6차 추출단계에서는 홍삼군이 높게 나타났다. 백삼과 홍삼의 추출단계별 농축액의 조사포닌 함량은 백삼 $(56.44 \mathrm{mg} / \mathrm{g})$ 에 비해 홍삼 $(53.15 \mathrm{mg} / \mathrm{g})$ 이 약 $5.8 \%$ 증가하는 것으로 나타났다.

이들을 혼합한 선택적 홍삼농축액 모델 4종의 기호도 평가 결과 $1,2,6$ 차 추출물이 혼합된 RGB-4가 가장 높은 기호도를 나타내었고 시판 홍삼 농축액 3종에 대해 비교한 결과에서도 RGB-4가 쓴맛, 떫은맛, 인삼향 강도가 약해지 고 종합적 기호도에서 높은 평가를 받았다.

본 실험에서는 추출방법을 달리 함으로써 추출수율 및 조사포닌 함량을 감안하여 인삼 쓴맛과 향의 강도를 낮출 수 있다는 것을 확인하였다. 이 추출방법을 이용하여 쓴맛 을 저감시키고 인삼향미의 강도를 저감시킨 제품을 개발하 여 좀 더 편하고 자연스럽게 홍삼제품을 접할 수 있도록 더 많은 연구가 진행 되어야 할 것이다.

\section{감사의 글}

본 연구는 농림축산식품부 수출전략기술개발사업(과제 번호 : 312064-3)의 연구개발비 지원에 의해 수행되었으며, 이에 감사드립니다.

\section{References}

1. Kim YC, Cho CW, Rhee YK, Yoo KM, Rho JH (2007) Antioxidant activity of ginseng extracts prepared by enzyme and heat treatment. J Korean Soc Food Sci Nutr, 36, 1482-1485

2. Park JW, Han IS, Suh SI, Beaek WK, Suh MH, Bea JH, Choe BK (1996) Effects of ginseng saponin on the cytokine gene expression in human immune system. Korean J Ginseng Sci 20, 15-22

3. Park HJ, Park KM, Rhee MH, Song YB, Choi KJ, Lee JH, Kim SC Park KH (1996) Effect of ginsenoside Rb1 on rat liver phosphoproteins induced by carbon tetrachloride. Biol Pharm Bull, 19, 834-838
4. Shin HR, Kim JY, Yun TK, Morgan G, Vainio H (2000) The cancer-preventive potential of panax ginseng: A review of human and experimental evidence. Cancer Cause Control 11, 565-576

5. Kim WY, Kim JM, Han SB, Lee SK, Kim ND, Park MK (2000) Steaming of ginseng at high temperature enhances biological activity. J Nat Prod, 63, 1702-1704

6. Xie JT, Mehendale SR, Li X, Quigg R, Wang X, Wang CZ, Wu JA, Aung HH, Rue PA, Bell GI, Yuan CS (2005) Anti-diabetic effect of ginsenoside $\mathrm{Re}$ in $o b / o b$ mice. Biochim Biophys Acta, 1740, 319-325

7. Kim H, Chen X, Gillis CN (1992) Ginsenosides protect pulmonary vascular endothelium against free radical induced injury. Biochem Biophy Res Commun, 189, 670-676

8. Kim ST, Jang JH, Kwon JH, Moon KD (2009) Changes in the chemical components of red and white ginseng after puffing. Korean J Food Preserv, 16, 355-361

9. Ko SK, Lee CR, Choi YE, Im BO (2003) Analysis of ginsenosides of white and red ginseng concentrates. Korean J Food Sci Technol, 35, 536-539

10. Kong BM, Park MJ, Min JW, Kim HB, Kim SH, Kim SY, Yang DC (2008) Physico-chemical characteristics of white, fermented and red ginseng extracts. J Ginseng Res, 32, 238-243

11. Ryu KH (2003) Present status of red ginseng products and its manufacturing process, Food Ind Nutr, 8, 38-42

12. AOAC (1990) Official Method of Analysis. 15th ed, Association of Official Analytical Chemists, Washington DC, p 777-784

13. Shibata S, Tanaka T, Ando T, Sado M, Tsushima S, Ohsawa T (1966) Chemical studies on oriental plant drugs(XIV) protopanaxadiol, a genuine sapogenin of ginseng saponins. Chem Pharm Bull, 14, 595-600

14. Do JH, Lee HO, Lee SK, Jang JK, Lee SD, Sung HS (1993) Colorimetric determination of acidic polysaccharide from Panax ginseng, its extraction condition and stability. Korean J Ginseng Sci, 17, 139-144

15. Choi YJ, Hwang KH (2011) Analysis of the extraction condition of soluble acidic polysaccharides from ginseng marc. Kor J Phamacogn, 42, 82-88

16. Han YN, Kim SY, Lee HJ, Hwang WI, Han BH (1992) Pattern-analysis of panax ginseng polysaccharide. Korean J Ginseng Sci, 16, 217-222

17. John E (2015) D. Suresh Kumar: Herbal bioactives and food fortification: Extraction and formulation. Chromatographia, 79,363 